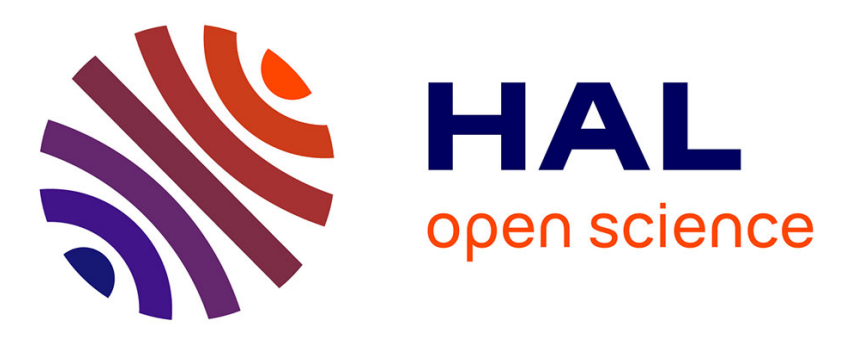

\title{
Synthesis and antimalarial activity of 2-methoxyprop-2-yl peroxides derivatives
}

Laure Cointeaux, Jean-François Berrien, Viviane Peyrou, Olivier Provot, Liliane Cicéron, Martin Danis, Anne Robert, B. Meunier, Joëlle Mayrargue

\section{- To cite this version:}

Laure Cointeaux, Jean-François Berrien, Viviane Peyrou, Olivier Provot, Liliane Cicéron, et al.. Synthesis and antimalarial activity of 2-methoxyprop-2-yl peroxides derivatives. Bioorganic and Medicinal Chemistry Letters, 2003, 13 (1), pp.75-77. 10.1016/S0960-894X(02)00837-5 . hal-02394637

\section{HAL Id: hal-02394637 \\ https://hal.science/hal-02394637}

Submitted on 4 Dec 2019

HAL is a multi-disciplinary open access archive for the deposit and dissemination of scientific research documents, whether they are published or not. The documents may come from teaching and research institutions in France or abroad, or from public or private research centers.
L'archive ouverte pluridisciplinaire HAL, est destinée au dépôt et à la diffusion de documents scientifiques de niveau recherche, publiés ou non, émanant des établissements d'enseignement et de recherche français ou étrangers, des laboratoires publics ou privés. 


\title{
Synthesis and Antimalarial Activity of 2-Methoxyprop-2-yl peroxides derivatives.
}

\author{
Laure Cointeaux, ${ }^{\mathrm{a}}$ Jean-François Berrien, ${ }^{\text {a }}$ Viviane Peyrou, ${ }^{\mathrm{a}}$ Olivier Provot, ${ }^{\mathrm{a}}$ Liliane \\ Ciceron, ${ }^{\mathrm{b}}$ Martin Danis, ${ }^{\mathrm{b}}$ Anne Robert, ${ }^{\mathrm{c}}$ Bernard Meunier ${ }^{\mathrm{c}}$ and Joëlle Mayrargue.*a \\ a UPRES A 8076 BioCIS, Laboratoire de synthèse et conception des molécules d'intérêt thérapeutique, Faculté de \\ Pharmacie, rue J.-B. Clément, F-92296 Châtenay Malabry, France. b INSERM U511, Immuno-biologie cellulaire et \\ moléculaire des infections parasitaires, Groupe hospitalier Pitié-Salpétrière, F-75013 Paris, France. c Laboratoire de \\ Chimie de Coordination du CNRS, 205 route de Narbonne, 31077 Toulouse cedex 4, France.
}

\begin{abstract}
Methoxyprop-2-yl peroxides were synthesized and evaluated in vitro against Plasmodium falciparum. These acyclic artemisinin-related peroxides revealed moderate to good activity but were devoided of alkylating property towards the synthetic model of haeme $\mathrm{Mn}^{\mathrm{II}}-\mathrm{TPP}$.
\end{abstract}

Malaria is the most widespread infection disease. It is worldwide aspread and affects about 300 million people causing from one to three million deaths every year. Moreover Plasmodium resistance to classical therapy such as choroquine has considerably increased. Artemisinin 1 and related trioxanes have received considerable attention as alternative therapy since their fast antimalarial activity was maintained against chloroquine resistant strains of $P$. falciparum. ${ }^{1}$ Their antimalarial activity was dependent of endoperoxide interaction with intraparasitic haeme. Monoelectronic transfert from iron (II) to peroxide function resulted in the cleavage of endoperoxide bond with primary formation of an unstable oxygen centered radical, rearrangement and creation of a $\mathrm{C}$ centered radical. ${ }^{2}$ Such a radical was able to alkylate the haemin as it has been experimentally shown with manganese (II) tetraphenyl porphyrin $\left(\mathrm{Mn}^{\mathrm{II}}-\mathrm{TPP}\right)^{3}$ or more recently with haemin. ${ }^{4}$ That would be lethal for the parasite throught the accumulation of non polymerisable redoxactive haeme adducts. ${ }^{5}$ These radicals may also be responsible for the alkylation of proteins ${ }^{6,7}$ and that could also be lethal for the Plasmodium. ${ }^{7}$ However, the final mechanism responsible of the death of the parasite has not yet been definitely determined. ${ }^{8}$

As a part of our research on antimalarial peroxide with simple synthetic access, we focused our attention on 2methoxyprop-2-yl peroxides 2. These perketals have been previously developped by Dussault as useful synthetic precursors of hydroperoxides. ${ }^{9}$ We used this procedure which proved to be a far superior method compared to others for preparing our sensitive hydroperoxides. ${ }^{10}$ We have also focused our attention on these simple accessed linear perketals $\mathbf{2}$ for their biological properties. We reported recently their powerful trichomonacidal activity. ${ }^{11,12}$ Anaerobic Trichomonas vaginalis was for example ten times more sensible to 2-methoxyprop-2-yl hexadec-1-yl peroxide than to the reference compound Metronidazole. ${ }^{12}$

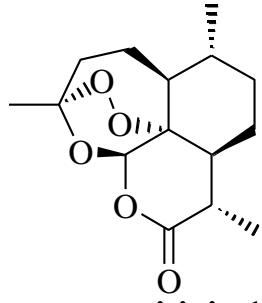

artemisinin 1

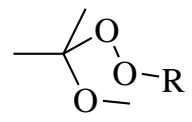

perketals 2
Figure 1.

Perketals 2 could also constituted acyclic analogues of artemisinin $\mathbf{1}$ and related trioxanes since they both contained an $\alpha$-alkoxyperoxide function essential for antimalarial activity. ${ }^{13}$ We reported herein the synthesis 
and antimalarial activity of a series of 2-methoxyprop2-yl peroxides.

\section{Synthesis}

2-methoxyprop-2-yl peroxides were prepared according to Dussault procedure, i.e. ozonolysis of 2,3dimethylbutene $\mathbf{3}$ in methanol afforded 2-methoxyprop2-yl hydroperoxide 4 that reacted with alkyl bromides 5a-p under mild conditions to give perketals 2a-p into moderate to good yields. ${ }^{11,12}$

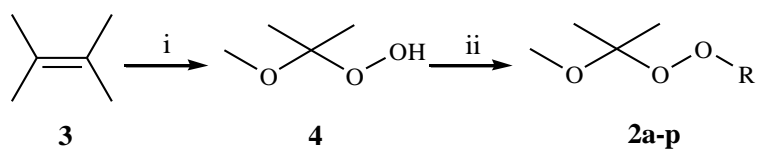

Scheme 1. Synthesis of perketals 2a-p. Reagents and conditions: (i) $\mathrm{O}_{3}$, $\mathrm{MeOH},-78^{\circ} \mathrm{C}$. (ii) RBr 5a-p, CsOH, BHT, DMF, RT.

\section{Antimalarial activity}

Perketals 2a-p were evaluated in vitro against $P$. falciparum FCR3 strain. ${ }^{14}$ They all revealed antimalarial activity with $\mathrm{IC}_{50}$ ranging from $10^{-5}$ to $10^{-7} \mathrm{M}$. The most active compounds $(\mathbf{2 k}, \mathbf{2 m})$ were about one eighth of the antimalarial potency of artemisinin on this strain, and were substituted with alkyl pinenyl group. Other perketals 2 with apolar radical chain tested herein had medium to good activities. The less active compounds had an alkyl chain substituted with a polar moiety i.e. a nitrile (2h), an ester (2i) or in a lesser extent an ether function (2g). Previously reported arachidonic acid derived Dussault perketals had an alkenyl chain, end substituted with $\mathrm{CH}_{2}-\mathrm{CH}_{2}-\mathrm{CO}_{2} \mathrm{H}$ or $\mathrm{O}-\mathrm{CH}_{2}-\mathrm{CO}_{2} \mathrm{H}$. They showed a weak activity against $P$. falciparum (respectively 36 and $14 \%$ inhibition in vitro at $4.10^{-5}$ M). It appeared clearly that introduction of a polar function on this alkyl chain is deleterious for a good antimalarial activity.

\section{Alkylating properties}

Two of the most potent compounds, $\mathbf{2 k}$ and $\mathbf{2 m}$ were evaluated for they alkylating property of the haeme following the Meunier model. ${ }^{3}$ They both were incubated with a manganese (II) complex of tetraphenylporphyrin generated in situ by $n-\mathrm{Bu}_{4} \mathrm{NBH}_{4}$ reduction of $\mathrm{Mn}^{\mathrm{III}}(\mathrm{TPP}) \mathrm{Cl}$. After demetallation, the tetraphenyl-porphyrin was recovered unchanged in both cases. These perketals $\mathbf{2 k}, \mathbf{m}$ didn't alkylated haeme model, as unlike artemisinin ${ }^{3}$ and other related trioxanes. ${ }^{15}$ However it was not excluded that they could interact with haeme to generate radicals that had no haeme alkylating property as it was reported for other peroxides. ${ }^{16}$ They showed a different mechanism of action albeit they could be assimilated to linear trioxane analogues.

Table 1. Structure and in vitro antimalarial activities of compounds 2a-p against FCR3 P. falciparum strain.

\begin{tabular}{|c|c|c|}
\hline Compound $^{\mathrm{a}, \mathrm{b}}$ & Structure & $\begin{array}{l}\text { Activity } \\
\mathrm{IC}_{50}, \mathrm{nM}\end{array}$ \\
\hline $2 a^{a}$ & & $1650^{\mathrm{d}}$ \\
\hline $2 \mathbf{b}^{\mathrm{b}}$ & & $1550^{\mathrm{e}}$ \\
\hline $2 c^{b}$ & & $800^{\mathrm{e}}$ \\
\hline $2 d^{b}$ & & $2600^{\mathrm{e}}$ \\
\hline $2 \mathrm{e}^{\mathrm{b}}$ & & $520^{\mathrm{e}}$ \\
\hline $2 \mathrm{f}^{\mathrm{a}}$ & & $660^{\mathrm{e}}$ \\
\hline $2 \mathrm{~g}^{\mathrm{a}}$ & & $3200^{\mathrm{e}}$ \\
\hline $2 h^{b}$ & & $12800^{\mathrm{e}}$ \\
\hline $2 \mathrm{i}$ & & $6950^{\mathrm{e}}$ \\
\hline $2 \mathrm{j}^{\mathrm{b}}$ & & $870^{\circ}$ \\
\hline $2 k^{\mathrm{a}}$ & & $370^{\mathrm{d}}$ \\
\hline $2 \mathrm{I}^{\mathrm{b}}$ & & $600^{\circ}$ \\
\hline $2 \mathrm{~m}$ & & $480^{\mathrm{d}}$ \\
\hline $2 n^{b}$ & & $670^{\circ}$ \\
\hline $20^{b}$ & & $440^{\circ}$ \\
\hline $2 p^{\mathrm{b}}$ & & $1330^{\mathrm{e}}$ \\
\hline Chloroquine & & $170^{\mathrm{e}}$ \\
\hline Artemisinin & & 55 \\
\hline Artemether & & 14 \\
\hline
\end{tabular}

For physicochemical data see ${ }^{\mathrm{a}}$ ref $11,{ }^{\mathrm{b}}$ ref $12 .{ }^{\mathrm{c}}$ experiments were conducted in duplicate. ${ }^{\mathrm{d}}$ artemisinin was the reference compound. ${ }^{\mathrm{e}}$ artemether was the reference compound.

\section{Acknowledgements.}

We thank Dr. Jacqueline Mahuteau and Mrs. Sophie Mairesse-Lebrun for valuable assistance on NMR study and elemental analyses.

\section{References}

1. Alin, M.; Bjoerkman, A.; Landberg-Lindgren, A.; Ashton, M.; Trans.R. Soc. Trop. Med. Hyg. 1992, 86, 365-367.

2. Cumming, J. N.; Ploypradith, P. Posner, G. H. Adv. Pharmacol. 1997, 37, 253-297.

3. Robert, A.; Cazelles, J.; Meunier, B. Angew. Chem. Int. Ed. 2001, 40, 1954-1957.

4. Robert, A.; Coppel, Y.; Meunier, B. Chem. Commun. 2002, 5, 414-416.

5. Pandey, A. V.; Tekwani, B. L.; Singh, R. L.; Chauhan, V. S. J. Biol. Chem. 1999, 274, 383- 
388.

6. Bhisutthibhan, J.; Pan, X. Q.; Hossler, P. A.; Walker, D. J.; Yowell, C. A.; Carlton, J. J. Biol. Chem. 1998, 273, 192-198.

7. Asawamahasakda, W.; Ittarat, I.; Pu, Y.M.; Ziffer, H.; Meshnick, S. R. Antimicrob. Agents Chemother. 1994, 38, 1854-1858.

8. (a) Olliaro, P.; Haynes, R. K.; Meunier, B.; Yuthavong, Y. Trends Parasitol. 2001, 17, 122126. (b) Robert, A.; Meunier, B. Chem. Soc. Rev. 1998, 27, 273-279.

9. (a) Dussault, P.; Sahli, A. J. Org. Chem. 1992, 57, 1009-1012. (b) Dussault, P. Synlett 1995, 9971003.

10. Cointeaux, L.; Berrien, J.-F.; Mayrargue, J. submited to Tetrahedron Lett.

11. Camuzat-Dedenis, B.; Provot, O.; Cointeaux, L.; Peyrou, V.; Berrien, J.-F.; Bories, C.; Loiseau, P. M.; Mayrargue, J. Eur. J. Med. Chem. 2001, 36, 837-842.

12. Cointeaux, L.; Berrien, J.-F.; Camuzat-Dedenis, B.; Peyrou, V.; Provot, O.; Bories, C.; Loiseau, P. M.; Mayrargue, J. Il Farmaco, in press.

13. Pitt, M. J.; Easton, C. J.; Robertson, T. A.; Kumaratilake, L. M.; Ferrante, A.; Poulos, A.; Rathjen, D. A. Tetrahedron Lett. 1998, 39, 44014404.

14. Desjardins, R. E.; Canfield, C. J.; Haynes, J. D.; Chulay, J. D. Antimicrob. Agents Ch. 1979, 16, 710-718.

15. Robert, A.; Meunier, B. Chem. Eur. J. 1998, 4, 1287-1296.

16. Cazelles, J.; Camuzat-Dedenis, B.; Provot, O.; Robert, A.; Mayrargue, J.; Meunier, B. Perkin 1 2000, 8, 1265-1270. 